\title{
PERBEDAAN WAKTU AKTIVITAS LALAT BUAH TERHADAP ATRAKTAN EKSTRAK DAUN KEMANGI (Ocimum americana L.) DI KEBUN MANGGA KABUPATEN MAJALENGKA
}

\author{
Ineu Yuantika1', Jeti Rachawati², Taupik Sopyan² \\ 1 Universitas Galuh, J. R. E. Martadinata No.150, Ciamis, Indonesia \\ 2Universitas Galuh, Jl. R. E. Martadinata No.150, Ciamis, Indonesia
}

\begin{abstract}
Fruit flies are one of the main pests that are detrimental to farmers as well as threaten fruit production centers that can attack plants, one of which is mango. This study aims to determine the activity time of fruit flies on the attractant of basil leaf extract with clove leaf extract. This research was conducted in May 2016 in the mango garden of Sidamukti Village, Majalengka Regency. The method used is an experimental method of research design Randomized Block Design (RAK) which consists of three treatments and 10 replications. Samples of fruit flies were caught using a Steiner trap (bottles of mineral water) which were given the lure agent methyl eugenol from basil leaf extract with cloves. Observations for the study of daily activity time were carried out in the morning (06.00 - 08.00 WIB), afternoon (11.00 - 13.00 WIB), and in the afternoon (16.00 - $18.00 \mathrm{WIB}$ ) for 18 days. The research parameter was the number of fruit flies trapped in the morning, afternoon, and evening. Data analysis using ANOVA followed by Duncan's test with a significance level of $5 \%$ and $1 \%$. The results showed that fruit flies were more active during the day at 11.00-13.00 WIB. The most influential climatic factor on fruit fly activity is light.
\end{abstract}

Keywords: Activity time, Mango, basil leaf extract, fruit fly.

\begin{abstract}
ABSTRAK
Lalat buah merupakan salah satu hama utama yang merugikan bagi petani sekaligus mengancam sentra produksi buah yang dapat menyerang tanaman salah satunya mangga. Penelitian ini bertujuan mengetahui waktu aktivitas lalat buah terhadap atraktan ekstrak daun kemangi dengan ekstrak daun cengkeh. Penelitian ini dilaksanakan pada bulan Mei 2016 di kebun mangga Desa Sidamukti Kabupaten Majalengka. Metode yang digunakan adalah metode eksperimen desain penelitian Rancangan Acak Kelompok (RAK) yang terdiri atas tiga perlakuan dan 10 kali ulangan. Sampel lalat buah ditangkap dengan menggunakan perangkap Steiner (botol bekas air mineral) yang diberi zat pemikat metil eugenol dari ekstrak daun kemangi dengan cengkeh. Pengamatan untuk kajian waktu aktivitas harian dilakukan pada pagi hari (06.00 - 08.00 WIB), siang hari (11.00 - 13.00 WIB), dan sore hari (16.00 - 18.00 WIB) selama 18 hari. Parameter penelitian adalah jumlah lalat buah yang terperangkap pada pagi, siang, dan sore. Analisis data menggunakan ANAVA dilanjutkan uji Duncan dengan taraf nyata $5 \%$ dan $1 \%$. Hasil penelitian menunjukkan lalat buah lebih aktif pada siang hari pukul 11.00 - 13.00 WIB. Faktor klimatik yang paling berpengaruh terhadap aktivitas lalat buah adalah cahaya.
\end{abstract}

Kata kunci: Waktu aktivitas, Mangga, ekstrak daun kemangi, lalat buah.

Cara sitasi: Yuantika, I., Rachmawati,J. \& Sopyan, T. (2021). Perbedaan Waktu Aktivitas Lalat Buah Terhadap Atraktan Ekstrak Daun Kemangi (Ocimum americana L.) Di Kebun Mangga Kabupaten Majalengka. Bioed: Jurnal Pendidikan Biologi, 9 (2), 41-45. 


\section{PENDAHULUAN}

Kabupaten Majalengka merupakan salah satu pusat produksi buah-buahan, khususnya Mangga jenis "Gedong Gincu" yang merupakan jenis unggulan daerah tersebut sekaligus produk daerah secara nasional maupun pada skala ekspor (Saptana et al., 2005). Penolakan ekspor buah mangga oleh beberapa negara dikarenakan waktu tempuh (distribusi) yang cukup lama sehingga begitu sampai di negara tujuan, buah mangga mengalami pembusukan karena lalat buah (Mukti, 2013).

Lalat buah merupakan salah satu hama yang merugikan bagi petani sekaligus dapat mengancam sentra produksi buah yang dapat menyerang tanaman salah satunya mangga. Hama lalat buah dapat menimbulkan kerugian mencapai 30-60\% pada perkebunan mangga (Kuswadi, 2001).

Kerusakan akibat serangan lalat buah ditemukan terutama pada buah yang hampir masak. Gejala awal ditandai dengan adanya lubang kecil di kulitnya bekas tusukan ovipositor lalat betina saat meletakkan telur ke dalam buah. Bekas tusukan semakin meluas sebagai akibat perkembangan larva yang memakan daging buah sehingga buah menjadi busuk sebelum buah masak (Haq et al., 2012).

Banyak petani menggunakan insektisida kimia sebagai salah satu komponen untuk mengendalikan hama serangga. Penggunaan insektisida kimia harus dilakukan secara bijaksana berkaitan dengan kemungkinan dampak negatif yang ditimbulkan (Kartasapoetra, 1993). Penggunaan Insektisida kimia dapat digantikan dengan menggunakan insektisida nabati yang berasal dari tanaman. Tanaman yang dapat digunakan untuk insektisida nabati harus mengandung Metil eugenol dan bersifat atraktan (penarik) bagi hama lalat buah (Kardinan, 2003).

Metil eugenol dapat dihasilkan dari tanaman Selasih (Ocimum basilicum L.), Daun Legundi (Vitex trifolia), daun wangi (Melaeuca bracteata), daun kemangi (Ocimum americana L.) dan daun cengkeh (Syzigium aromaticum) (Towaha, 2012). Tanaman yang dipakai pada peneliti ini yaitu daun kemangi (Ocimum americana L.). Kandungan senyawa Metil eugenol pada daun kemangi sebesar 52,27 \% (Singkhornart et al., 2009).

Lalat buah merupakan serangga yang menyukai cahaya, sehingga untuk melakukan aktivitas hidupnya lalat buah membutuhkan cahaya. Kelembapan yang rendah dapat meningkatkan mortalitas imago yang baru keluar dari pupa. Kelembapan udara yang terlalu tinggi (95-100\%) dapat mengurangi laju peletakan telur (Siwi, 2005). Serangga ini membutuhkan suhu rendah $25-30^{\circ} \mathrm{C}$, bagi kehidupannya (Sulfiani, 2014). Saat musim buah tiba Serangga ini terbang mencari buah yang menjelang masak untuk bertelur (Kalie, 2000).

Lalat buah aktif pada pagi hingga siang hari sekitar pukul 10.00-14.00 WIB, sedangkan pada waktu sore hari sekitar pukul 16.00-18.00 WIB merupakan akhir dari aktivitas lalat buah (Manurung et al., 2012). Sedangkan menurut Broto, (2003) aktivitas terbang lalat buah yaitu pada pagi hari pukul 06.00-09.00 dan sore hari pukul 15.00-18.00, dan menurut Putra, (1997) aktivitas makan lalat buah berlangsung antara pukul 07.0010.00 .

Penelitian bertujuan untuk mengetahui waktu aktivitas lalat buah sehingga dapat menentukan kapan waktu pengendalian lalat buah dilakukan dalam mencegah atau menggagalkan proses perkawinan lalat buah sehingga kerusakan mangga berkurang.

\section{METODE PENELITIAN}

Penelitian dilakukan di kebun Mangga Desa Ciandeu Sidamukti Kecamatan Majalengka Kabupaten Majalengka. Pemerangkapan lalat buah dilakukan dengan menggunakan tipe steiner yang telah dimodifikasi dari botol bekas air mineral berukuran $1500 \mathrm{ml}$. Perangkap dipasang dengan melilitkan kapas yang sudah dibasahi dengan $2 \mathrm{ml}$ ekstrak daun kemangi. Penggantian kapas dilakukan setiap dua hari sekali atau ketika kapas terkena air hujan. Ekstrak daun kemangi diperoleh dengan cara dikering anginkan selama beberapa hari sampai daun kering, kemudian daun tersebut disuling dengan menggunakan alat penyulingan yang biasa digunakan oleh petani agar menghasilkan minyak (ekstrak) untuk dapat digunakan sebagai atraktan dalam menarik lalat buah.

Perangkap digantung pada pohon mangga pada ketinggian 1,5-2 meter dari permukaan tanah. Perangkap dipasang sehari sebelum pengamatan dilakukan pada sore hari secara acak. Jumlah keseluruhan 16 perangkap,. Jarak antara plot ekstrak kemangi satu dengan lainnya sekitar 4 meter. Pengamatan dilakukan pada waktu pagi sekitar pukul 06.00-08.00, siang sekitar pukul 11.00-13.00, dan sore hari sekitar pukul 16.0018.00 WIB pada setiap harinya. Setelah sampel diambil kemudian membandingkan banyaknya lalat buah yang terperangkap antara pagi, siang, dan sore hari dengan cara menghitungnya. Lalat buah yang paling banyak terperangkap menunjukkan waktu aktivitas lalat buah, sedangkan lalat buah yang terperangkap dalam jumlah sedikit menunjukkan berkurangnya aktivitas lalat buah karena dipengaruhi oleh faktor lingkungan. 
Parameter yang diamati selain waktu aktivitas lalat buah yaitu mengamati faktor klimatik seperti intensitas cahaya, suhu udara, kelembapan udara, curah hujan, dan kecepatan angin. Waktu pengambilan data dilakukan selama 18 hari dengan pengamatan setiap hari sebanyak 16 kali ulangan. Pengamatan dihentikan setelah 18 hari. Untuk mengetahui signifikansi perbedaan waktu aktivitas lalat buah pada pagi, siang, dan sore hari, teknik analisis data yang digunakan adalah ANAVA dilanjutkan dengan Uji Dun-can dengan taraf nyata $5 \%$ dan $1 \%$ dengan 10 kali ulangan (Gomes, 2010).

\section{HASIL DAN PEMBAHASAN}

Hasil yang diperoleh pada penelitian ini menunjukkan lalat buah yang paling banyak terperangkap adalah jenis Bactrocera carambolae. Perangkap ekstrak daun kemangi (Ocimum americana L.) memiliki waktu aktivitas harian yang lebih aktif pada siang hari pukul 11.00 - 13.00 WIB ditunjukkan oleh banyaknya jumlah lalat buah yang terperangkap dan diberi ekstrak daun kemangi yang bersifat atraktan. Grafik waktu aktivitas lalat buah pada ekstrak daun kemangi (O. americana L.) dapat dilihat pada gambar 1.

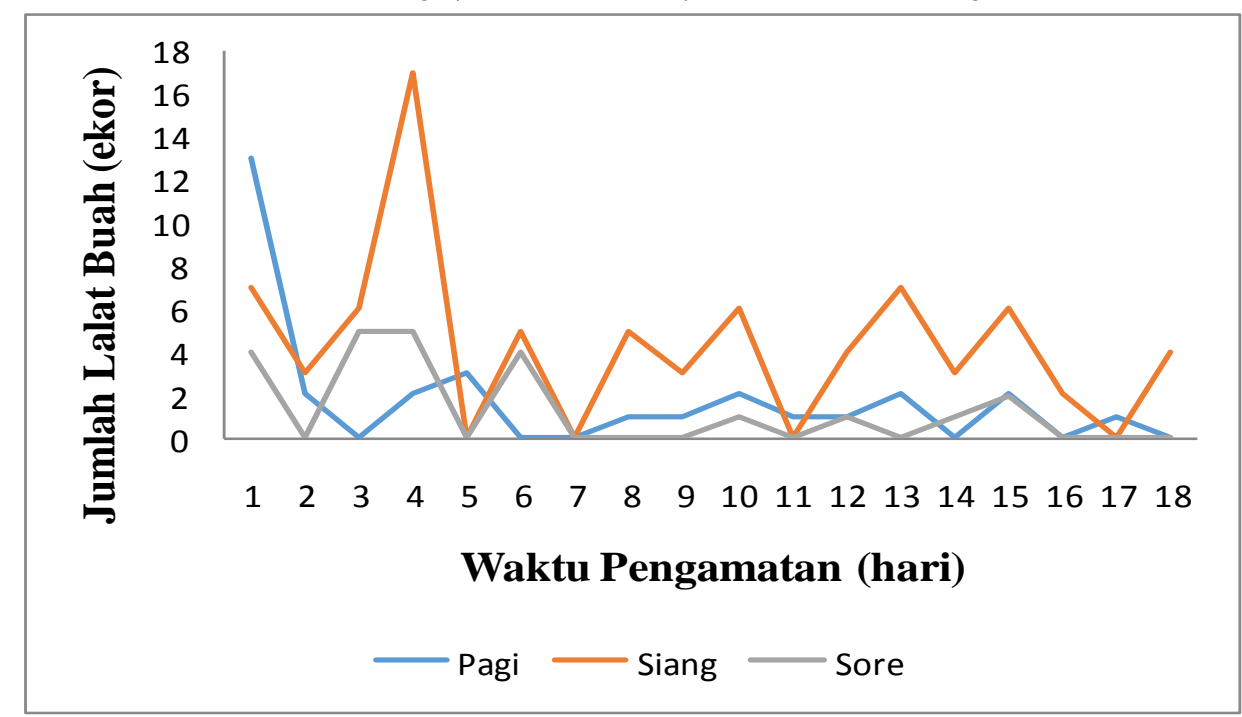

Gambar 1 Waktu aktivitas lalat buah pada ekstrak daun kemangi (Ocimum americana L.) pada waktu pagi, siang, dan sore hari di kebun Mangga Kabupaten Majalengka pada bulan Mei 2016.

Gambar 1 menunjukkan bahwa waktu aktivitas lalat buah pada ekstrak daun kemangi (O. americana L.) di kebun Mangga Kabupaten Majalengka aktif pada siang hari pukul 11.00 - 13.00 WIB.

Tabel 1. Proporsi lalat buah yang tertangkap pada perangkap ekstrak daun kemangi (Ocimum americana L.) dari pukul 06.00 - 18.00 WIB pada pertanaman mangga (Mangifera indica L.) di Kabupaten Majalengka Jawa Barat

\begin{tabular}{lrcc}
\hline No & Waktu & Jumlah tangkapan (ekor) & Proporsi \\
\hline 1 & $06.00-08.00$ & 31 & $23.48 \% \mathrm{a}$ \\
2 & $11.00-13.00$ & 78 & $59.09 \% \mathrm{~b}$ \\
3 & $16.00-18.00$ & 23 & $17.42 \% \mathrm{a}$
\end{tabular}

Ket. Angka diikuti huruf yang sama menunjukkan pengaruh yang tidak berbeda nyata pada taraf nyata $5 \%$ dan $1 \%$.

Tabel 1 menunjukkan bahwa Hasil pengamatan menunjukkan terdapat perbedaan waktu aktivitas lalat buah pada waktu pagi, siang, dan sore pada ekstrak daun kemangi (O. americana L.). Proporsi lalat buah yang tertangkap paling banyak pada waktu siang hari pukul $11.00-13.00$ WIB dengan jumlah tangkapan 78 ekor dan proporsi sekitar 59,09\%. Hal ini didukung pendapat Manurung et al. (2012) bahwa lalat buah lebih aktif pada siang hari yaitu pada pukul $10.00-12.00$ WIB. lalat buah pada pagi dan sore hari sedikit. Jumlah lalat buah yang paling banyak terperangkap dapat menunjukkan waktu aktivitas lalat buah.

Hasil teknik analisis data menggunakan ANAVA menunjukkan perbedaan waktu aktif lalat buah tersebut berbeda sangat nyata. Banyaknya jumlah lalat buah pada siang hari $(11.00-13.00 \mathrm{WIB})$ dan sebaliknya relatif sedikitnya jumlah lalat buah pada pagi hari pukul $06.00-08.00$ WIB dan sore hari pukul 16.00 
- 18.00 WIB erat kaitannya dengan sifat lalat buah yang menyukai cahaya. Berdasarkan kondisi klimatik di lokasi penelitian diketahui bahwa rata-rata intensitas cahaya pada pagi hari sekitar 275 lux , siang hari sekitar 885 lux, dan sore hari sekitar 91 lux. Kondisi suhu di lokasi penelitian diketahui rata-rata suhu pada pagi hari sekitar $27,8^{\circ} \mathrm{C}$, siang hari sekitar $31,4^{\circ} \mathrm{C}$, dan sore hari sekitar $30,5^{\circ} \mathrm{C}$. Me-nurut Sulfiani (2014) lalat buah membutuhkan suhu sekitar $25-30^{\circ} \mathrm{C}$ bagi kehidupannya. Suhu yang terlalu tinggi dapat menyengat tubuhnya (Kalie, 2000).

Kondisi suhu lingkungan yang melebihi suhu optimum dapat menyebabkan sedikitnya proporsi lalat buah yang tertangkap pada pagi, siang, dan sore hari. Suhu yang baik untuk hidup lalat buah apabila dilihat dari hasil penelitian di lapangan yaitu pada waktu pagi dan sore hari, namun pada waktu pagi dan sore hari intensitas cahaya matahari yang rendah. Hal tersebut didukung oleh pendapat Siwi, (2005) Lalat buah merupakan serangga yang membutuhkan cahaya matahari untuk melakukan aktivitasnya. Lalat buah aktif pada keadaan terang, yaitu pada siang hari. Intensitas cahaya yang paling tinggi di lokasi penelitan yaitu sekitar 885 lux dan baik untuk aktivitas lalat buah. Berdasarkan data pengamatan di lapangan diketahui bahwa suhu udara di lokasi penelitian kurang cocok untuk aktivitas lalat buah karena melebihi batas optimum sehingga jumlah proporsi lalat buah yang tertangkap sedikit.

Curah hujan mempunyai pengaruh yang kuat terhadap kelimpahan buah inang dan populasi lalat buah dewasa. Curah hujan yang tinggi juga menyebabkan populasi lalat buah meningkat, dan daya hidup lalat buah yang berada di dataran tinggi umumnya lebih lama dibandingkan dengan dataran rendah (Herlinda et al., 2007). Kelembapan yang rendah dapat meningkatkan mortalitas imago yang baru keluar dari pupa. Kelembapan udara yang terlalu tinggi (95-100\%) dapat mengurangi laju peletakan telur. Semakin tinggi kelembapan udara maka lama perkembangan akan semakin panjang. Lalat buah dapat hidup baik pada kelembapan antara $62-90 \%$ (Siwi, 2005). Berdasarkan kondisi klimatik di lokasi penelitian diketahui bahwa rata-rata kelembapan udara pada pagi hari sekitar $91,8 \%$, siang hari sekitar $91,6 \%$, dan sore hari sekitar $90,1 \%$. Kondisi di lokasi penelitian tersebut merupakan kondisi yang baik untuk hidup lalat buah. Berdasarkan hasil survei rata-rata curah hujan di Kebun Mangga Desa Ciandeu Sidamukti Kecamatan Majalengka Kabupaten Majalengka sekitar 2000 - 3000 $\mathrm{mm} / \mathrm{tahun}$.

Intensitas serangan dan populasi lalat buah akan meningkat saat kecepatan angin rendah (Herlinda et al., 2007). Kecepatan angin di lokasi penelitian sekitar $0,12 \mathrm{~m} / \mathrm{s}$. Maka, dengan kecepatan angin yang tidak terlalu kencang sangat baik untuk peningkatan populasi hidup lalat buah. Lalat buah akan terbang ke semaksemak ketika angin kencang untuk berlindung (Kalie, 2000).

Perangkap yang diberi ekstrak daun kemangi (O. americana L.) dapat menarik lalat buah karena senyawa atraktan (penarik) yang terdapat pada ekstrak daun kemangi lebih dominan dibanding repellen. Hal ini disebabkan kandungan senyawa Metil eugenol pada daun kemangi sebesar 52,7 \% Singkhornart et al., (2009). Tertariknya lalat buah pada ekstrak daun kemangi maka diketahui waktu aktivitas lalat buah.

Berdasarkan pengamatan di lapangan, pohon mangga yang ada di Kebun Mangga Desa Ciandeu Sidamukti Kecamatan Majalengka Kabupaten Majalengka tampaknya belum berbuah. Munculnya buah mangga ada hubungannya dengan proporsi lalat buah yang tertangkap, karena munculnya buah sangat penting untuk lalat buah dalam peletakan telur.

\section{KESIMPULAN}

Berdasarkan hasil penelitian lalat buah pada pertanaman mangga di Kabupaten Majalengka Provinsi Jawa Barat dapat disimpulkan terdapat perbedaan waktu aktivitas lalat buah (Bactrocera carambolae) terhadap atraktan ekstrak daun kemangi (O. americana L.) bahwa lalat buah lebih aktif pada siang hari pukul $11.00-$ 13.00 WIB dibandingkan dengan waktu pagi hari (06.00 - 08.00 WIB) dan sore hari (16.00 - 18.00 WIB).

\section{PERSANTUNAN}

Terimakasih kepada Kelompok Tani Ciandeu Desa Sidamukti, Kecamatan Majalengka, Kabupaten Majalengka, Provinsi Jawa Barat, atas izinnya sehingga Penelitian ini terlaksana.

\section{DAFTAR PUSTAKA}

Alma, M.H., M. Ertas, S. Nitz and H. Kollmannsberger. 2007. Chemi-cal composition and content of essential oil from the bud of cultivated Turkish clove (Syzy-gium aromaticum L.). Bio Resources 2 (2): 265-269.

Endah, J. dan Novizan. 2002. Me-ngendalikan Hama Penyakit Tanaman. Jakarta: Agro Media Pustaka

Gomes, K. A., dan Gomez., A. A. (2010). Prosedur Statistika untuk Penelitian PertanianEdisi Ke-dua. Jakarta: UI-Press. 
Haq R, Khan MF dan Haq E. 2012. Heavy Weight Protein Affected by Lead Acetate in Bactrocє. u usrsalis. J. Of Basic and Applied Sciences 8: 411-415.

Herlinda S, Reka M, Triani A dan Yulia P. 2007. Populasi dan Serangan Lalat Buah Bactrocera dorsalis (HENDEL) (Diptera : Tephri-tidae) serta Potensi Parasit-oidnya Pada Pertanaman Cabai (Capsicum annuum L.). Seminar ar Nasional dan Kongres IImu Pengetahuan Wilayah Barat. Palembang.

Kali, M.B 2000. Mengatasi Buah Rontok, Busuk, dan Berulat. Jakarta: Penebar Swadaya.

Kardinan, A. 2003. Pestisida Nabati Ramuan dan Aplikasi. PS. Jakarta.

Kardinan, A. 2005. Penggunaan Atraktan Nabati Untuk Me-ngendalikan Hama Lalat Buah dalam Sistem Pertanian Or-ganik. Prosiding Workshop Mas-yarakat Pertanian Organik Indonesia. HIm.145-155.

Kardinan, A. 2009. Tanaman Pe-ngendali Lalat Buah. Agromedia Pustaka. Jakarta.

Kartasapoetra, A.G 1993. Hama Ta-naman Pangan Dan Perkebun-an. Jakarta: Bumi Aksara.

Kuswadi, A.N. 2001. Pengendalian Terpadu Hama Lalat Buah Bactrocera dorsalis hendel Dengan Teknik Serangga Man-dul dan Atraktan, Tersedia: http://www.ristek.or.id/rut/teknologi/hasil/pertanian/PHT/hama lalat buah html. [17 Januari 2016].

Manohara, D. dan R. Novariza. 1999. Potensi Tanaman Rempah dan Obat Sebagai Pengendali Jamur Phytopthora capsici. Prosiding Forum Komunikasi Ilmiah Pe-manfaatan Pestisida Nabati. HIm.406-421.

Manurung, B., Puji, P. dan Emmi, E. T. 2012. Pola Aktivitas Harian Dan Dinamika Populasi Lalat Buah Bactrocera Dorsalis Com-plex Pada Pertanaman Jeruk Di Dataran Tinggi Kabupaten Karo Provinsi Sumatera Utara. J. HPT Tropika. Vol. 12(2) : $103-110$.

Mukti, G.W., 2013. Strategi Pe-ngembangan Agribisnis Mangga Untuk Memenuhi Pasar Ekspor Kabupaten Majalengka Propinsi Jawa Barat. Universitas Padja-jaran Bandung.

Saptana EH, Lestari KS, Indraningsih, Ashari, Sunarsih, \& Darwis, 2005. Pengembangan Model Kelembagaan Kemitraan Usaha Yang Berdaya Saing di Kawa-san Sentra Produksi Hortikul-tura. Laporan Akhir Penelitian Proyek/Bagian Proyek Pengkaji-an Teknologi Pertanian Partisi-patif. Pusat Penelitian dan Pengembangan Sosial Ekonomi Pertanian. Bogor.

Singkhornart, S., Laohakunjit, N., Kerdchoechuen, o. and Chat-paisarn, A. 2009. Identification of Major Compounds from 3 Labiatae Oils Extracted. Agri-cultural Sci. J. 40 : 1 (Suppl.) : 95-98.

Siwi S.S. 2005. Eko-biologi Hama Lalat Buah. Bogor. BB-Biogen.

Sodiq, M. 2009. Ketahanan Tanaman Terhadap Hama. UPN Press. ISBN: 978-979-3100-53-1.

Sulfiani . 2014. Preferensi Lalat Buah (Bactrocera spp) Terhadap Atraktan Alami Pada Pertanam-an Cabai Rawit (Capsicum frutescent). Tesis Universitas Hasanuddin Makasar. p. 105. Tidak diterbitkan.

Towaha, J. (2012). "Manfaat Eugenol Cengkeh dalam Berbagai In-dustri di Indonesia". Perspek-tif. Volume 11 (2): 79 